Vol.59: e16160241, January-December 2016 http://dx.doi.org/10.1590/1678-4324-2016160241 ISSN 1678-4324 Online Edition
BRAZILIAN ARCHIVES OF BIOLOGY AND TECHNOLOGY

AN INTERNATIONAL JOURNAL

\title{
Impact of Fungicide Residues on Polymerase Chain Reaction and on Yeast Metabolism
}

\author{
Gildo Almeida da Silva ${ }^{1 *}$, Taís Letícia Bernardi ${ }^{2}$, Patrícia Dayane Carvalho Schaker ${ }^{1}$, \\ Bruna Carla Agustini ${ }^{1}$, Loiva Maria de Mello ${ }^{1}$, Patrícia Valente ${ }^{3}$. \\ ${ }^{1}$ Embrapa Uva e Vinho - Laboratório de Microbiologia, Bento Gonçalves, Brazil; ${ }^{2}$ Instituto Federal de Educação \\ Ciência e Tecnologia do Rio Grande do Sul, Sertão, Rio Grande do Sul, Brasil; ${ }^{3}$ Universidade Federal do Rio \\ Grande do Sul, Porto Alegre, Rio Grande do Sul, Brasil.
}

\begin{abstract}
The indiscriminate use of pesticides on grape crops is harmful for consumers' healthin "in natura" consumption and in the ingestion of wine and grape juice. During winemaking, a rapid and efficient fermentation stage is critical to avoid proliferation of contaminating microorganisms and to guarantee the product's quality. Polymerase chain reaction (PCR) has the advantage of detecting these contaminants in the early stages of fermentation. However,this enzymatic reaction may also be susceptible to specific problems, reducing its efficiency. Agricultural practices, such as fungicide treatments, may be a source of PCR inhibiting factors and may also interfere in the normal course of fermentation.The action of the pesticides captan and folpet on PCR and on yeast metabolism was evaluated, once these phthalimide compounds are widely employed in Brazilian vineyards. DNA amplification was only observed at 75 and $37.5 \mu \mathrm{g} / \mathrm{mL}$ of captan concentrations, whereas with folpet, amplification was observed only in the two lowest concentrations tested $(42.2$ and $21.1 \mu \mathrm{g} / \mathrm{mL}$ ). Besides the strong inhibition on Taq polymerase activity, phthalimides also inhibited yeast metabolism at all concentrations analyzed.Grape must containing captan and folpet residues could not be transformed into wine due to stuck fermentation caused by the inhibition of yeast metabolism. Noncompliance with the waiting period for phthalimide fungicides may result in financial liabilities to the viticulture sector.The use of yeasts with high fungicide sensitivity should be selected for must fermentation as a strategy for sustainable wine production and to assure that products comply with health and food safety standards.
\end{abstract}

Key words: fungicide;PCR inhibitors; stuck fermentation;Taq polymerase inhibitors; yeast growth

\footnotetext{
*Authors for correspondence: gildo.almeida@embrapa.br
} 


\section{INTRODUCTION}

Disease occurrences in vineyards, especially fungal ones, have led to an indiscriminate use of fungicides for their control. However, this practice has serious implications on the residues of these compounds in grapes, grape must and wines. Despite the well-known health hazard for consumers, fungicides residues are connected with stuck and sluggish alcoholic fermentation with costs increase for wineries, resulting from the fungicides' negative effects on yeast growth .

Moreover, sluggish fermentation causes the proliferation of contaminant microorganisms, which reduce wine quality due to the production of off-flavour metabolites. A rapid and efficient detection of these microorganisms may reduce the damage to the final product. In this context, the polymerase chain reaction (PCR) is a wellestablished molecular technique for the identification of microorganisms in food, beverages and other environments. This cultureindependent technique has many advantages such as sensitivity and specificity, although it may also have huge limitations concerning primer annealing and false negative occurrences. Failure in some analyses is referred to the Taq polymerase susceptibility to natural inhibitors (proteins, polysaccharides, ethanol, tannic acid) present in materials such as skeletal material, tea, soil, biological fluids and food. Additional procedures involving physical or enzymatic strategies to remove the inhibitors are necessary in all cases. All these procedures result in a significant loss of DNA, especially when its quantity is limited. External chemical compounds can also be involved in Taq DNA polymerase inhibition and once phthalimides are widely employed in Brazilian vineyards to control fungal threats, the main purpose of the current research was to detect the activity of two fungicides named captan $(\mathrm{N}$ trichloromethylthio-4-cyclohexane-1,2-

dicarboximide, $\mathrm{C}_{9} \mathrm{H}_{8} \mathrm{Cl}_{3} \mathrm{NO}_{2} \mathrm{~S}$ ) and folpet (Ntrichloromethylthiophthalimide, $\quad \mathrm{C}_{9} \mathrm{H}_{8} \mathrm{Cl}_{3} \mathrm{NO}_{2} \mathrm{~S}$ ) upon the enzyme Taq DNA polymerase and upon the metabolic activity of the yeast Saccharomyces cerevisiae, which is the main yeast in the winemaking process.

\section{MATERIAL AND METHODS}

\section{MICROORGANISM, DNA EXTRACTION, PCR AND ELECTROPHORESIS PROCEDURES}

Saccharomyces cerevisiae Embrapa 1vvt/97 was employed as autochthonous standard yeast that has been used for industrial winemaking in southern Brazil. The strain belongs to the Yeast Culture Collection (WDCM 1056) of EMBRAPA Grapes and Wine (Brazilian Agricultural Research Corporation). The yeast strain was stored in cryogenic vials at $-80^{\circ} \mathrm{C}$. The cryogenic vial was defrosted at room temperature to reactivate the microorganism. A $10 \quad \mu l$ aliquot was then transferred to Petri dishes containing must agar $(10 \mathrm{~g} / \mathrm{L}$ yeast extract; $250 \mathrm{~mL}$ white grape must; 20 $\mathrm{g} / \mathrm{L}$ agar). The plate was incubated for $24-48$ hours at $25{ }^{\circ} \mathrm{C}$ for the growth of yeast cells growth. A freeze-thawing process was performed for DNA extraction. Hence, a $10^{7}$ cell.ml ${ }^{-1}$ yeast suspension was stored at $-18^{\circ} \mathrm{C}$ until ice formation, which was then thawed at room temperature.

Primers YeastF (5'CTTAGTTGGTGGAGTGATTTG-3') and YeastR (5'-GGTACTAGCGACGGGCG-3'), targeting the conserved region of $18 \mathrm{~S}$ rDNA, amplified a 375-bp fragment and PCR amplification was performed in $25 \mu \mathrm{L}$ reaction volume. One microliter of DNA template was added to the PCR master mixture, which consisted of 1x PCR buffer (Invitrogen Corporation, USA), $1.5 \mathrm{U}$ of Taq DNA polymerase Platinum (Invitrogen Corporation, USA), $0.1 \mathrm{mM}$ of each dNTP (Invitrogen Corporation, USA), $0.8 \mathrm{pM}$ of each primer (Integrated DNA Technologies Inc., USA), $2.5 \mathrm{mM}$ of $\mathrm{MgCl}_{2}$ and $15.45 \mu \mathrm{L}$ of captan solutions (concentrations ranging between recommended dose $1200 \mu \mathrm{g} / \mathrm{mL}$ and $3.75 \mu \mathrm{g} / \mathrm{mL}$ ) or folpet solutions (concentrations ranging between recommended dose $675 \mu \mathrm{g} / \mathrm{mL}$ and 4.22 $\mu \mathrm{g} / \mathrm{mL}$ ). Amplification consisted of an initial denaturation at $94^{\circ} \mathrm{C}$ for $5 \mathrm{~min}$, followed by 30 cycles of denaturation at $94^{\circ} \mathrm{C}$ for $30 \mathrm{~s}$, annealing at $68^{\circ} \mathrm{C}$ for $45 \mathrm{~s}$, extension at $72^{\circ} \mathrm{C}$ for $30 \mathrm{~s}$, with a final extension at $72^{\circ} \mathrm{C}$ for $5 \mathrm{~min}$. The PCR reactions were conducted on a PTC-100 Peltier thermal cycler (Bio-Rad Life Sciences, USA).

PCR products were resolved in $1 \%$ agarose gel electrophoresis. The gels were stained with ethidium bromide $(0.5 \mu \mathrm{g} / \mathrm{mL})$ and stained DNA was visualized under $302 \mathrm{~nm}$ UV light on 
transilluminator Eagle Eye II Video Imaging System (Stratagene, California, USA). The fragment's size was estimated by comparison with 100-bp DNA ladder (Invitrogen, USA).

\section{FERMENTATION, CELL GROWTH, VIABILITY AND ANALYTICAL PROCEDURE}

The effect of different concentrations of captan (between 1200 and $37.5 \mu \mathrm{g} / \mathrm{mL}$ ) and folpet (between 675 and $21.1 \mu \mathrm{g} / \mathrm{mL}$ ) upon yeast metabolism was measured by $\mathrm{CO}_{2}$ evolution, following .

The growth of Saccharomyces cerevisiae was evaluated by optical density (OD) readings at 600 $\mathrm{nm}$ in a $1 \mathrm{~cm}$-path quartz cuvette using a spectrophotometer UV/VIS Lambda Bio (PerkinElmer). The yeast cells were inoculated to a final concentration of $10^{7}$ cell $/ \mathrm{mL}$ in a fungicide-free $150-\mathrm{mL}$ grape must, or containing either 37.5 $\mu \mathrm{g} / \mathrm{mL}$ of captan or $21.1 \mu \mathrm{g} / \mathrm{mL}$ of folpet. Each treatment was performed in triplicate. The cultures were incubated at $25^{\circ} \mathrm{C}$ in an orbital shaker (New Brunswick, Edison, USA) at $150 \mathrm{rpm}$ during 96 hours.

Cells' morphology after 4 days of fermentation was observed with an optical universal microscope Zeiss (Carl-Zeiss, Oberkochen, Germany) equipped with phase contrast. Cell viability on captan and folpan presence was determined with NucleoCounter YC-100 (Gibertini, Milan, Italy).

The concentration of sugar was estimated by the phenol/sulphuric acid method, described by and ethanol evaluation was done by distillation as described elsewhere, with an electronic distiller (Gibertini, Italy), followed by measurement of density with Anton Paar DMA45 Calculating Digital Density Meter SP2 (Graz, Austria) equipped with Haake D3/L (Germany) water bath. Percentage by volume at $20^{\circ} \mathrm{C}$ of ethyl alcohol corresponding to apparent specific gravity was obtained.

\section{RESULTS AND DISCUSSION}

\section{EFFECT OF PHTHALIMIDES ON PCR}

Figure 1 shows the effect of different folpet and captan concentrations on the amplification reaction with $1.5 \mathrm{U}$ Taq DNA polymerase. The highest concentration for DNA amplification was $42.2 \mu \mathrm{g} / \mathrm{mL}$ and $75 \mu \mathrm{g} / \mathrm{mL}$ respectively for folpet and captan. PCR inhibition may be due to the binding of agents to single-stranded or double-stranded DNA preventing amplification and to interference with Taq DNA polymerase, blocking or reducing enzyme activity. also reported that Taq DNA polymerase is completely inhibited by compounds isolated from the marine red alga Symphyocladia latiuscula.

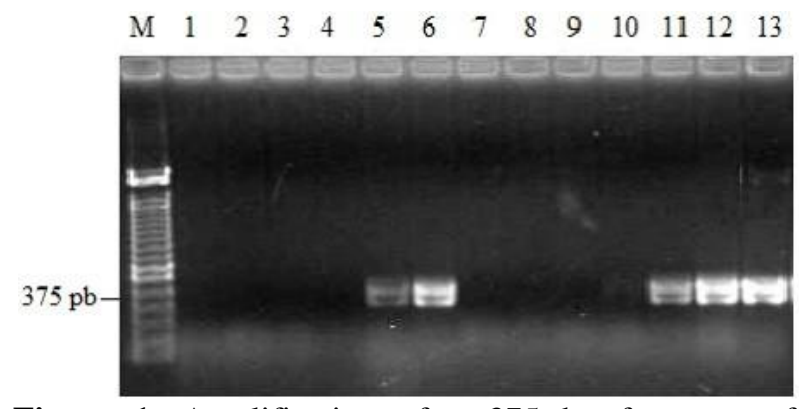

Figure 1. Amplification of a 375 bp fragment of Saccharomyces cerevisiae DNA at different folpet and captan levels employing 1.5 U Taq DNA polymerase. Lane M (100 bp DNA Ladder); Lanes 1 - 6 represent decreasing concentrations of folpet: 675, 337.5, 168.7, 84.4, 42.4 and $21.1 \mu \mathrm{g} / \mathrm{mL}$; Lanes 7 - 12 represent decreasing concentrations of captan: 1200, 600, 300, 150, 75, $37.5 \mu \mathrm{g} / \mathrm{mL}$; Lane 13 (positive control).

Further, enzyme concentration was increased from 1.5 to 6.0 units and all the other components in the $25-\mu \mathrm{L}$ reaction mixture were constant to show that the action of these fungicides is on Taq DNA polymerase. Results demonstrated that, in a $25 \mu \mathrm{L}$ reaction mixture containing 1.5 units of Taq DNA polymerase, the enzyme was completely inhibited by captan at concentrations 120 and $60 \mu \mathrm{g} / \mathrm{mL}$, whereas significant inhibition was only observed at $120 \mu \mathrm{g} / \mathrm{mL}$ concentration with 6.0 units of Taq DNA polymerase (data not given). A similar behaviour has also been reported for the competition between DNA and folpet. Employing 1.5 units of Taq DNA polymerase, the enzyme was completely inhibited by folpet at $67.5 \mu \mathrm{g} / \mathrm{mL}$ concentration, whereas no inhibition was observed with 6.0 units of Taq DNA polymerase (data not given).

DNA polymerase is a multifaceted enzyme with distinct activities, or rather, it has polymerase and exonuclease activities. 
According to , captan affects the polymerising step and influences the activities of both exonucleases, inhibiting 3'-5' exonuclease and polymerase activities while enhancing 5'-3' exonuclease activity. Current results suggest that the fungicide is irreversibly bound to the enzyme and not to other components of the reaction. demonstrated that the binding of captan occurs at the $\beta$ subunit of RNA polymerase, which contains the nucleoside triphosphate-(NTP)-binding site, and consequently blocks the latter.

\section{EFFECT OF PHTHALIMIDES ON CELL METABOLISM}

Results (Figure 2A and B) corroborated the fact that all concentrations in which captan and folpet were not inhibitory to Taq DNA polymerase, strongly inhibited $\mathrm{CO}_{2}$ evolution and suggested that the inhibitory action on Saccharomyces cerevisiae's anaerobic metabolism is clearly attributed to these compounds.
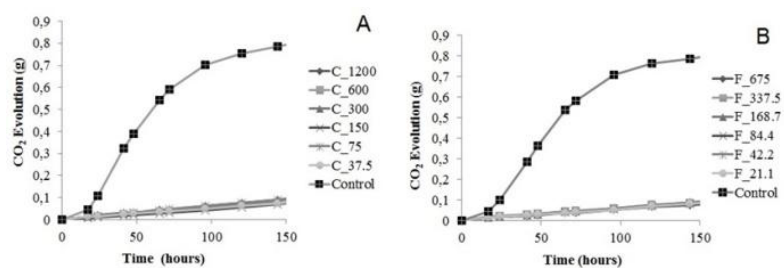

Figure 2. Metabolic activity of Saccharomyces cerevisiae at different concentrations of (A) Captan 1200, 600, 300, 150, 75 and $37.5 \mu \mathrm{g} / \mathrm{mL}$ and (B) Folpet $675,337.5,168.7,84.4,42.2$ and $21.1 \mu \mathrm{g} / \mathrm{mL}$.

In fact, ethanol production and product yield $(\mathrm{Yp} / \mathrm{s})$ were severely affected by the two added compounds (Figure $3 \mathrm{~A}$ and B). Drastic inhibition took place even when the cells were inoculated at the lowest levels of folpet and captan, $21.1 \mu \mathrm{g} / \mathrm{mL}$ and $37.5 \mu \mathrm{g} / \mathrm{mL}$, respectively. These results suggest different interpretations. The effect of these two chemical compounds on yeast seems not to be only due to the inhibitory activity of Taq DNA or RNA polymerases but also to a severe inhibition that reaches the glycolytic pathway or only at one point involving pyruvic acid, acetaldehyde and ethanol with the respective
$\mathrm{CO}_{2}$ evolution. In this case, the glycolytic $\mathrm{CO}_{2}$ evolution would be more sensitive to these compounds than aerobic respiration. This differential behaviour has been attributed to several organic compounds that induce the alcoholic fermentation and cause a decrease in the specific oxygen uptake rate (Verduyn et al., 1992). If the ethanol production is tightly bound to the growth of yeast cells, indicating that yeast must be produced as a co-product , the media for yeast cell growth should also be free of the chemical compounds captan and folpet.
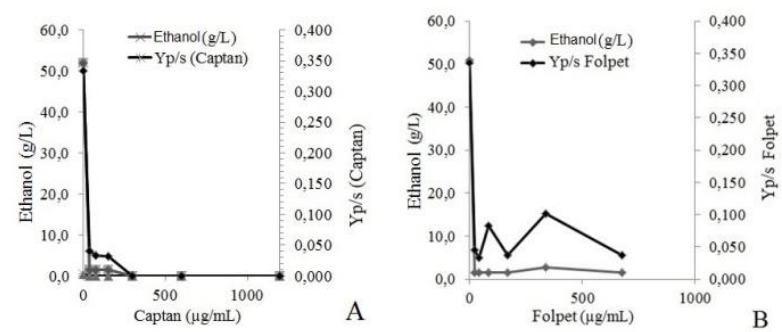

Figure 3. Influence of different concentrations of Captan and Folpet on ethanol production and product yield $\left(\mathrm{Y}_{\mathrm{p} / \mathrm{s}}\right)$ by Saccharomyces cerevisiae

Yeast growth, measured by optical density, was strongly inhibited by these chemical compounds. The cells were more severely affected by captan (Figure 4) and the inhibition process of these chemicals reached the aerobic and anaerobic cell metabolism. In this case, the action of these compounds should be linked to a point somewhere in the glycolytic pathway in which inhibition affects the alcoholic fermentation and aerobic metabolism. 


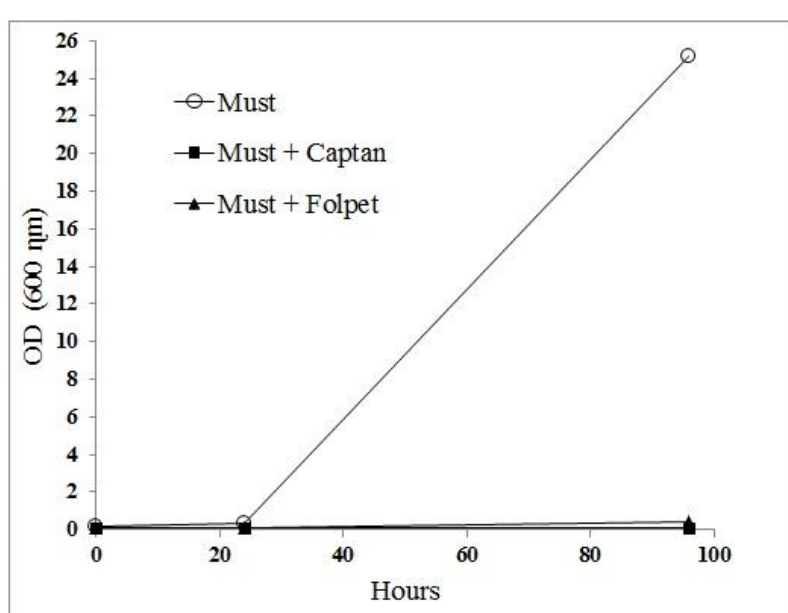

Figure 4. Growth inhibition of Saccharomyces cerevisiae during a 96-hour period with $37.5 \mu \mathrm{g} / \mathrm{mL}$ of Captan and $21.1 \mu \mathrm{g} / \mathrm{mL}$ of Folpet.

observed that folpet and its decomposition product thiophosgene caused changes in absorbance profiles of glyceraldehyde 3phosphate dehydrogenase and that these changes were associated with the inhibition of dehydrogenase activity, suggesting an effect on the protein's tertiary configuration and/or denaturation. Glyceraldehyde 3-phosphate dehydrogenase is a crucial glycolytic enzyme that mediates the transfer of an inorganic phosphate to a glyceraldehyde 3-phosphate molecule, the production of a $\mathrm{NADH}^{+} \mathrm{H}^{+}$ molecule and the formation of a molecule of 1.3-diphosphoglyceric acid. Thiophosgene is a highly reactive compound that reacts with cellular groups to form several different products. Besides this reactive property, thiophosgene behaves as an activator in the synthesis of neoglycoprotein . The pyranose derivatives of various monosaccharides bind to a large protein of the medium, forming neoglycoprotein and so preventing the diffusion of sugar into the yeast cells. These characteristics of thiophosgene may partially explain the severe inhibition of the yeast cell activities. Both trichloromethylthio $\left(\mathrm{SCCl}_{3}\right)$ and thiophosgene $\left(\mathrm{SCC}_{12}\right)$ may react with several important cellular molecules. Glutathione (g-glutamyl-cysteinyl-glycine) (GSH), one of these molecules, is a key component that participates in the cellular detoxification process and mediates a great diversity of other complex cellular activities . GSH depletion is associated more with augmented oxidation of water-soluble proteins than with the lipid peroxidation of cell membranes and induces apoptosis in Saccharomyces cerevisiae. GSH plays an important role not only in the growth of nitrogen-fixing bacteria but also in their symbiotic processes. The growth and fermentation inhibition observed in Saccharomyces cerevisiae provoked by captan and folpet is related to decrease of intracellular GSH levels. Captan and folpet, reacting directly with GSH or inhibiting the enzymes of glutathione metabolism, may decrease the life span of yeast cells and have an enormous lethal effect on Saccharomyces cerevisiae. Microscopic analysis has shown several cells completely lysed after four days of growth in the medium with $37.5 \mu \mathrm{g} . \mathrm{mL}^{-1}$ of captan and $21.1 \mu \mathrm{g} . \mathrm{mL}^{-1}$ of folpet. Several dead cells presented budding. The fact that both budding and non-budding yeast cells were being destroyed suggested that these compounds killed the yeast cells irrespective of their particular cell cycle stage. No excess lysis was found in the medium without the addition of these two chemical compounds. Cells' viability was measured in a 24-hour-old culture (Figure 5). The strong lysis process detected in must treated with the two chemical compounds suggested that the must, although a rich complex medium with all the necessary nutrients required for yeast metabolism, did not neutralise the compounds' deleterious effects. showed that the basal respiration of fungi was not affected by captan but approximately $40 \%$ of the glucose-activated respiration was inhibited by the compound. These facts show that the components of the medium not only did not protect the yeast cells against chemical products but also intensified their inhibitory actions. This behaviour is very similar to the very well-known penicillin mechanism of action. It has been known for a long time that these antibiotics inhibit susceptible bacteria more effectively when the environment is most favourable for growth . 


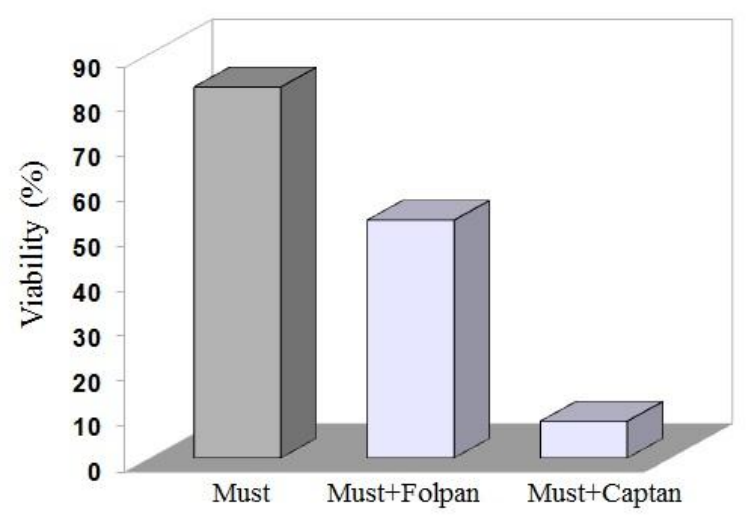

Figure 5. Viability of a 24-hour culture of Saccharomyces cerevisiae with and without $37.5 \mu \mathrm{g} / \mathrm{mL}$ of Captan and $21.1 \mu \mathrm{g} / \mathrm{mL}$ of Folpet.

Contrastingly, some fungicides did not affect the ethanol production and their presence could even stimulate alcoholic fermentation . Captan and folpet have proved to be more potent inhibitor compounds for anaerobic and aerobic metabolism of Saccharomyces cerevisiae than for Taq DNA polymerase activity. Differences among strains related to these inhibitors may exist. If the above statement is true, the yeast is probably one of those sensitive strains. However, these results highlight the importance of respecting the waiting period between the last fungicide application and harvest time. Private and public viticulture technicians recommend 60 days for a secure waiting period to assure an adequate fermentation process. The grape must containing captan and folpet residues could neither be transformed into wine due to the inhibition of yeast metabolism nor the fermentation process would reach completion.

\section{CONCLUSIONS}

Residues of phthalimides affect Taq polymerase activity and impair the identification or detection of microorganism by PCR. Moreover, noncompliance with the waiting period for phthalimide fungicides may result in financial liabilities to the viticulture sector due to stuck fermentation. The use of yeasts with high fungicide sensitivity should be selected for must fermentation as a strategy for sustainable wine production and to assure products in compliance to health and food safety standards.

\section{ACKNOWLEDGEMENTS}

The authors would like to thank the Brazilian funding agencies CAPES (Coordenação de Aperfeiçoamento de Pessoal de Nível Superior) and CNPq (Conselho Nacional de Pesquisa).

\section{REFERENCES}

1- Calhelha RC, Andrade JV, Ferreira IC, Estevinho LM. Toxicity effects of fungicide residues on the wine-producing process. Food Microbiol. 2006; 23(4): 393-398.

2- Čuš F, Raspor P. The effect of pyrimethanil on the growth of wine yeasts. Lett Appl Microbiol. 2008; 47(1): 54-59.

3- Desnos-Ollivier M, Bretagne S, Dromer F, Lortholary O, Dannaoui E. Molecular identification of black-grain mycetoma agents. J Clin Microbiol. 2006; 44(10): 3517-3523.

4- Agustini BC, Silva LP, Bloch C, Jr., Bonfim TM, da Silva GA. Evaluation of MALDI-TOF mass spectrometry for identification of environmental yeasts and development of supplementary database. Appl Microbiol Biotechnol. 2014; 98(12): 5645-5654.

5- Usbeck JC, Wilde C, Bertrand D, Behr J, Vogel RF. Wine yeast typing by MALDI-TOF MS. Appl Microbiol Biotechnol. 2014; 98(8): 3737-3752.

6- Cattaneo C, Smillie DM, Gelsthorpe K, Piccinini A, Gelsthorpe AR, Sokol RJ. A simple method for extracting DNA from old skeletal material. Forensic Sci Int. 1995; 74(3): 167-174.

7- Tichopad A, Polster J, Pecen L, Pfaffl MW. Model of inhibition of Thermus aquaticus polymerase and Moloney murine leukemia virus reverse transcriptase by tea polyphenols (+)-catechin and (-)epigallocatechin-3-gallate. J Ethnopharmacol. 2005; 99(2): 221-227.

8- Kermekchiev MB, Kirilova LI, Vail EE, Barnes WM. Mutants of Taq DNA polymerase resistant to PCR inhibitors allow DNA amplification from whole blood and crude soil samples. Nucleic Acids Res. 2009; 37(5).

9- Schrader C, Schielke A, Ellerbroek L, Johne R. PCR inhibitors - occurrence, properties and removal. $J$ Appl Microbiol. 2012; 113(5): 1014-1026.

10- Meng X, Li B, Chen Z, Yao L, Zhao D, Yang X, et al. Inhibition of a thermophilic deoxyribonucleic acid polymerase by fullerene derivatives. J Enzyme Inhib Med Chem. 2007; 22(3): 293-296.

11- da Silva GA, Bernardi TL, Schaker PDC, Menegotto M, Valente P. Rapid Yeast DNA Extraction By Boiling And Freeze-Thawing Without 
Using Chemical Reagents And DNA Purification. Braz Arch Biol Techn. 2012; 55(2): 319-327.

12- Giudici P, Zambonelli C. Biometric and GeneticStudy on Acetic-Acid Production for Breeding of Wine Yeast. Am J Enol Viticult. 1992; 43(4): 370374.

13- Dubois M, Gilles KA, Hamilton JK, Rebers P, Smith F. Colorimetric method for determiantion of sugars and related substances. Anal Chem. 1956; 28: 350-356.

14- Ribéreau-Gayon J, Peynaud E, Sudraud P, Ribéreau-Gayon P. Siences et techniques du vin. Paris: Dunod; 1982.

15- Jin HJ, Oh MY, Jin DH, Hong YK. Identification of a Taq DNA polymerase inhibitor from the red seaweed Symphyocladia latiuscula. J Environ Biol. 2008; 29(4): 475-478.

16- Freeman-Wittig MJ, Welch W, Jr., Lewis RA. Binding of captan to DNA polymerase I from Escherichia coli and the concomitant effect on 5'----3' exonuclease activity. Biochemistry. 1989; 28(7): 2843-2849.

17- Luo G, Lewis RA. Inhibition of RNA polymerase by captan at both DNA and substrate binding sites. Biochem Pharmacol. 1992; 44(11): 2251-2258.

18- Bai FW, Anderson WA, Moo-Young M. Ethanol fermentation technologies from sugar and starch feedstocks. Biotechnol Adv. 2008; 26(1): 89-105.

19- Siegel MR. Reactions of the fungicide folpet (N(trichloromethylthio)phthalimide) with a thiol protein. Pestic Biochem Phys. 1971; 1(2): 225-233.

20- Molema G, Jansen RW, Visser J, Herdewijn P, Moolenaar F, Meijer DKF. Neoglycoproteins as carriers for antiviral drugs: synthesis and analysis of protein-drug conjugates. J Med Chem. 1991; 34(3): 1137-1141.

21- Bi WX, Kong F, Hu XY, Cui X. Role of glutathione in detoxification of copper and cadmium by yeast cells having different abilities to express cup1 protein. Toxicol Mech Methods. 2007; 17(6): 371378.

22- Vergauwen B, Elegheert J, Dansercoer A, Devreese B, Savvides SN. Glutathione import in Haemophilus influenzae $\mathrm{Rd}$ is primed by the periplasmic hemebinding protein HbpA. P Natl Acad Sci USA. 2010; 107(30): 13270-13275.

23- Sedlak TW, Saleh M, Higginson DS, Paul BD, Juluri KR, Snyder SH. Bilirubin and glutathione have complementary antioxidant and cytoprotective roles. P Natl Acad Sci USA. 2009; 106(13): 5171-5176.

24- Madeo F, Frohlich E, Ligr M, Grey M, Sigrist SJ, Wolf DH, et al. Oxygen stress: a regulator of apoptosis in yeast. J Cell Biol. 1999; 145(4): 757 767.

25- Harrison J, Jamet A, Muglia CI, Van de Sype G, Aguilar OM, Puppo A, et al. Glutathione plays a fundamental role in growth and symbiotic capacity of
Sinorhizobium meliloti. J Bacteriol. 2005; 187(1): 168-174.

26- Siegel MR. Reactions of Certain Trichloromethyl Sulfenyl Fungicides with Low Molecular Weight Thiols - in-Vivo Studies with Cells of Saccharomyces-Pastorianus. J Agr Food Chem. 1970; 18(5): 823-\&.

27- Rousk J, Demoling L, Bååth E. Contrasting ShortTerm Antibiotic Effects on Respiration and Bacterial Growth Compromises the Validity of the Selective Respiratory Inhibition Technique to Distinguish Fungi and Bacteria. Microb Ecol. 2009; 58(1): 75-85.

28- Pratt R, Dufrenoy J. Cytochemical Interpretation of the Mechanism of Penicillin Action. Bacteriol Rev. 1948; 12(1): 79-103.

29- Caboni P, Cabras P. Chapter 2 - Pesticides' Influence on Wine Fermentation. In: Steve LT, editor. Advances in Food and Nutrition Research: Academic Press; 2010. p. 43-62.

Received: May 01, 2016; Accepted: June 22, 2016 